\title{
Serotonin receptors in depression: from A to B [version 1; peer
}

\section{review: 3 approved]}

\author{
Katherine M. Nautiyal ${ }^{1}$, René Hen ${ }^{1,2}$ \\ ${ }^{1}$ Division of Integrative Neuroscience, New York State Psychiatric Institute, and Department of Psychiatry, Columbia University, NY, \\ USA \\ ${ }^{2}$ Departments of Neuroscience and Pharmacology, Columbia University, NY, USA
}

\begin{tabular}{l} 
V1 First published: 09 Feb 2017, 6(F1000 Faculty Rev):123 \\
https://doi.org/10.12688/f1000research.9736.1 \\
Latest published: 09 Feb 2017, 6(F1000 Faculty Rev):123 \\
https://doi.org/10.12688/f1000research.9736.1 \\
\hline
\end{tabular}

\section{Abstract}

The role of serotonin in major depressive disorder (MDD) is the focus of accumulating clinical and preclinical research. The results of these studies reflect the complexity of serotonin signaling through many receptors, in a large number of brain regions, and throughout the lifespan. The role of the serotonin transporter in MDD has been highlighted in gene by environment association studies as well as its role as a critical player in the mechanism of the most effective antidepressant treatments - selective serotonin reuptake inhibitors. While the majority of the 15 known receptors for serotonin have been implicated in depression or depressive-like behavior, the serotonin $1 \mathrm{~A}$ $\left(5-\mathrm{HT}_{1 \mathrm{~A}}\right)$ and $1 \mathrm{~B}\left(5-\mathrm{HT}_{1 \mathrm{~B}}\right)$ receptors are among the most studied. Human brain imaging and genetic studies point to the involvement of $5-\mathrm{HT}_{1 \mathrm{~A}}$ and $5-\mathrm{HT}_{1 \mathrm{~B}}$ receptors in MDD and the response to antidepressant treatment. In rodents, the availability of tissue-specific and inducible knockout mouse lines has made possible the identification of the involvement of $5-\mathrm{HT}_{1 \mathrm{~A}}$ and $5-\mathrm{HT}_{1 \mathrm{~B}}$ receptors throughout development and in a cell-type specific manner. This, and other preclinical pharmacology work, shows that autoreceptor and heteroreceptor populations of these receptors have divergent roles in modulating depression-related behavior as well as responses to antidepressants and also have different functions during early postnatal development compared to during adulthood.

\section{Keywords}

serotonin, MDD, major depressive disorder, serotonin receptor, 5HT1A, 5-HT1B, 5-HTT, selective serotonin reuptake inhibitors, antidepressant

\section{Open Peer Review Approval Status \\ 12 \\ version 1 \\ 09 Feb 2017 \\ Faculty Reviews are review articles written by the prestigious Members of Faculty Opinions. The articles are commissioned and peer reviewed before publication to ensure that the final, published version is comprehensive and accessible. The reviewers who approved the final version are listed with their names and affiliations.}

1. John Neumaier, University of Washington, Seattle, USA

2. Randy Blakely, Charles E. Schmidt College of Medicine, Florida Atlantic University, Jupiter, USA

3. Irwin Lucki, University of Pennsylvania,

Philadelphia, USA

Any comments on the article can be found at the end of the article. 
Corresponding author: René Hen (rh95@columbia.edu)

Competing interests: The authors declare that they have no competing interests.

Grant information: The author(s) declared that no grants were involved in supporting this work.

Copyright: @ 2017 Nautiyal KM and Hen R. This is an open access article distributed under the terms of the Creative Commons Attribution License, which permits unrestricted use, distribution, and reproduction in any medium, provided the original work is properly cited. Data associated with the article are available under the terms of the Creative Commons Zero "No rights reserved" data waiver (CC0 1.0 Public domain dedication).

How to cite this article: Nautiyal KM and Hen R. Serotonin receptors in depression: from A to B [version 1; peer review: 3 approved] F1000Research 2017, 6(F1000 Faculty Rev):123 https://doi.org/10.12688/f1000research.9736.1

First published: 09 Feb 2017, 6(F1000 Faculty Rev):123 https://doi.org/10.12688/f1000research.9736.1 


\section{Introduction}

The serotonin hypothesis of depression has dominated the field of depression for over four decades ${ }^{1}$. This theory is centered on the idea that reduced serotonin signaling is a risk factor in the etiology and/or pathophysiology of major depressive disorder (MDD $)^{2}$. However, the most robust body of evidence for the role of serotonin in depression is the efficacy of increasing extracellular serotonin for the treatment of depression. The discovery that the efficacy of tricyclic antidepressants (TCAs) and monoamine oxidase inhibitor (MAOI) antidepressants was largely due to their serotonergic actions, which prompted the use of serotonin selective reuptake inhibitors (SSRIs), the first among them fluoxetine, to treat depression ${ }^{3-6}$. These drugs act at the serotonin transporter (5-HTT, also known as SERT) and cause increases in extracellular serotonin, which is the purported mechanism of action $^{6-8}$. Many subsequent drugs inhibiting serotonin reuptake have shown behavioral efficacy as antidepressant drugs, suggesting that increasing synaptic serotonin levels may lead to the treatment of depression ${ }^{6,9}$.

Despite the relative success in treating depression by increasing extracellular serotonin, there is a lack of strong evidence supporting a direct correlation between low serotonin signaling and depression. While some studies report an association between levels of platelet serotonin and depression, this has not been a consistent finding in large sample sets, and it is also unclear how platelet levels are related to brain levels of serotonin ${ }^{10,11}$. Additionally, few studies report direct correlations between cerebrospinal fluid 5-hydroxyindoleacetic acid (5-HIAA), a serotonin metabolite, and depression ${ }^{12,13}$. Low levels of tryptophan have been consistently linked to depression; however, these effects could be independent of serotonin ${ }^{14,15}$. The lack of consistent clear-cut abnormalities in global measures of serotonin signaling isn't surprising if one considers the complexity of the receptors at which serotonin binds, the intricate neuroanatomical circuitry of the serotonin system, and the developmental role serotonin plays as a neurotrophic factor ${ }^{16-18}$. Many recent studies have focused on understanding the mechanisms through which serotonin affects depression by studying the impact of 5-HTT and the 15 known receptors through gene-association studies, human brain imaging, and pharmacological and genetic mouse models ${ }^{19}$.

The success in treating depression by targeting the transporter with SSRIs prompted investigations into whether variability in 5-HTT expression levels could be involved in the etiology of depression. A highly cited study showed that there is an association between a polymorphism in the serotonin transporter (5-HTTLPR) and susceptibility to developing depression ${ }^{20}$. This and other studies have shown that the short "s" allele, which results in lower levels of 5-HTT expression (at least in vitro) and therefore increased extracellular 5-HT, is associated with a higher risk of depression when combined with stressful life events ${ }^{21,22}$. This discovery would be unexpected if developmental considerations were not considered. Although inhibiting the function of the transporter during adulthood decreases depressive symptoms as in the case of SSRIs, reduced expression of 5-HTT during development may increase depressive behavior in adulthood. A human functional magnetic resonance imaging (fMRI) study supports this, showing that short allele carriers show morphological and functional alterations in limbic circuits ${ }^{23}$. Additionally, mice lacking 5-HTT throughout life display increased depressive-like behaviors, and pharmacological blockade of 5-HTT in mice exclusively during early postnatal development resulted in increased adult depressive behavior ${ }^{24}$. These results highlight the differences in developmental versus adult effects of altered serotonin neurotransmission on depression.

In addition to the serotonin transporter, the majority of the 15 serotonin receptors have been implicated in the modulation of depression, depressive-like behaviors, or the response to antidepressant treatment ${ }^{19}$. There are numerous pre-clinical studies which have investigated the role of serotonin receptors using pharmacological manipulations and genetic knockout (KO) models in rodents (Table 1). Given the breadth of this literature, this review will focus on two receptors that are among the most extensively studied for their role in modulating depression, the 5-HT $\mathrm{HA}_{1 \mathrm{~A}}$ and $5-\mathrm{HT}_{1 \mathrm{~B}}$ receptor subtypes. In addition, attention will be paid to population-dependent and development-dependent effects of serotonin signaling at these receptors and will draw from both rodent and human studies.

The 5- $\mathrm{HT}_{1 \mathrm{~A}}$ and 5- $\mathrm{HT}_{1 \mathrm{~B}}$ receptors are both inhibitory Gi/o-coupled seven transmembrane receptors that are located throughout the brain $^{25-27}$. A major difference between these two receptors is their subcellular distribution ${ }^{28}$. 5-HT ${ }_{1 \mathrm{~A}}$ receptors are somatodendritic, while 5- $\mathrm{HT}_{1 \mathrm{~B}}$ receptors are located on axon terminals ${ }^{27,29}$. This difference is also reflected in their mechanisms of inhibitory action (Figure 1). Activation of either receptor causes decreased neurotransmitter release; however, $5-\mathrm{HT}_{1 \mathrm{~A}}$ receptor activation causes hyperpolarization, leading to decreased firing, while $5-\mathrm{HT}_{1 \mathrm{~B}}$ receptors inhibit voltage-gated calcium channels in the presynaptic terminal ${ }^{30-32}$. Another mechanism for 5-HT $1 \mathrm{~B}$ receptormediated inhibition is via effects on 5-HTT, and activation of the $5-\mathrm{HT}_{1 \mathrm{~B}}$ receptor increases serotonin reuptake $\mathrm{e}^{33,34}$.

Both 5- $\mathrm{HT}_{1 \mathrm{~A}}$ and 5- $\mathrm{HT}_{1 \mathrm{~B}}$ receptors act as autoreceptors located on serotonin neurons and also have heteroreceptor populations located on non-serotonin receptors (Figure 2). Although the mRNA in the raphe (corresponding to autoreceptors) is comparable between the two receptors, their heteroreceptors have distinct patterns of expression ${ }^{35}$. 5- $\mathrm{HT}_{1 \mathrm{~A}}$ receptors are enriched in the hippocampus and cortex, while 5- $\mathrm{HT}_{1 \mathrm{~B}}$ receptors are highly expressed in the basal ganglia ${ }^{36,37}$. These differences in mechanism of action and localization may play a role in the different functional effects of these receptors.

While this review focuses on the contribution of 5- $\mathrm{HT}_{1 \mathrm{~A}}$ and 5-HT receptors in depression and depressive-like behaviors, these receptors also modulate other psychiatric-relevant phenotypes. For example, alterations in 5- $\mathrm{HT}_{1 \mathrm{~A}}$ receptor expression influence anxiety behavior, and $5-\mathrm{HT}_{1 \mathrm{~B}}$ receptor signaling affects reward- and impulsivity-related phenotypes. These receptor-based differences in serotonergic regulation of emotional behavior, which segment into endophenotypes, could contribute to the heterogeneity of symptoms found in $\mathrm{MDD}^{38}$. Understanding the neural circuits that subserve these receptor-based and endophenotype-based 
Table 1. Preclinical evidence supporting the role for serotonin receptors in depression.

\begin{tabular}{|c|c|c|c|c|}
\hline Receptor & $\begin{array}{l}\text { PubMed } \\
\text { Hits }^{\star}\end{array}$ & $\begin{array}{l}\text { Pharmacological studies on } \\
\text { depression }\end{array}$ & $\begin{array}{l}\text { Genetic effects on } \\
\text { depression }\end{array}$ & $\begin{array}{l}\text { Other behavioral } \\
\text { phenotypes }\end{array}$ \\
\hline $5-\mathrm{HT}_{2 \mathrm{~A}}$ & 588 & $\begin{array}{l}\text { Antagonists have } \\
\text { antidepressant-like effects } \\
\text { and potentiate the effects of } \\
\text { SSRIs }^{133,134}\end{array}$ & $\begin{array}{l}\text { No known effect of } 5-\mathrm{HT}_{2 \mathrm{~A}} \\
\mathrm{KO} \text { on depressive-like } \\
\text { behavior }{ }^{135}\end{array}$ & $\begin{array}{l}\text { Agonists are hallucinogenic; } \\
\text { antagonists are } \\
\text { antipsychotic and anxiolytic; } \\
\text { KO mouse has reduced } \\
\text { anxiety-like behavior }{ }^{135-137}\end{array}$ \\
\hline $5-\mathrm{HT}_{2 \mathrm{~B}}$ & 52 & $\begin{array}{l}\text { Agonists have } \\
\text { antidepressant-like effects }{ }^{138}\end{array}$ & $\begin{array}{l}\text { Required for behavioral } \\
\text { effects of SSRIs }{ }^{138,139}\end{array}$ & $\begin{array}{l}\text { KO mouse shows increased } \\
\text { impulsivity }{ }^{140}\end{array}$ \\
\hline $5-\mathrm{HT}_{2 \mathrm{C}}$ & 282 & $\begin{array}{l}\text { Antagonists have } \\
\text { antidepressant-like effects; } \\
\text { agonists have pro-depressive } \\
\text { effects }^{141,142}\end{array}$ & $\begin{array}{l}\text { No known effect of } 5-\mathrm{HT}_{2 \mathrm{C}} \\
\mathrm{KO} \text { on depressive-like } \\
\text { behavior }\end{array}$ & $\begin{array}{l}\text { Antagonists have anxiolytic } \\
\text { effects; agonists decrease } \\
\text { impulsivity and motivation for } \\
\text { drug and food consumption; } \\
\text { KO mouse has reduced } \\
\text { anxiety-like behavior }{ }^{143-145}\end{array}$ \\
\hline $5-\mathrm{HT}_{3 \mathrm{~A}}$ & 252 & $\begin{array}{l}\text { Antagonist has } \\
\text { antidepressant-like effects }{ }^{146}\end{array}$ & $\begin{array}{l}5-\mathrm{HT}_{3} \text { required for } \\
\text { exercise-induced } \\
\text { antidepressant effects; } \mathrm{KO} \\
\text { has antidepressant-like } \\
\text { phenotype }^{147,148}\end{array}$ & Antagonists are anxiolytic ${ }^{149}$ \\
\hline $5-\mathrm{HT}_{4}$ & 81 & $\begin{array}{l}\text { Agonists have rapid } \\
\text { antidepressant-like } \\
\text { effects }\end{array}$ & $\begin{array}{l}\text { KO has attenuated } \\
\text { responses to stress }\end{array}$ & $\begin{array}{l}\text { Agonists are anxiolytic; } \\
\text { agonists improve cognitive } \\
\text { performance and reduce } \\
\text { feeding } 151,153\end{array}$ \\
\hline $5-\mathrm{HT}_{5 \mathrm{~A}}$ & 5 & Unknown & Unknown & $\begin{array}{l}\text { KO mice display increased } \\
\text { exploratory behavior }\end{array}$ \\
\hline $5-\mathrm{HT}_{6}$ & 62 & $\begin{array}{l}\text { Agonists produce } \\
\text { antidepressant-like effects } \\
\text { and antagonists block the } \\
\text { effects of SSRIs }^{155,156}\end{array}$ & Unknown & $\begin{array}{l}\text { Antagonists enhance } \\
\text { cognitive performance; } \\
\text { blockade of signaling is } \\
\text { anxiogenic }{ }^{157,158}\end{array}$ \\
\hline $5-\mathrm{HT}_{7}$ & 137 & $\begin{array}{l}\text { Antagonists have } \\
\text { antidepressant-like effects }{ }^{159}\end{array}$ & $\begin{array}{l}\text { KOs have an } \\
\text { antidepressant-like } \\
\text { phenotype }\end{array}$ & $\begin{array}{l}\text { Antagonists have } \\
\text { pro-cognitive effects }{ }^{160}\end{array}$ \\
\hline
\end{tabular}

*Number of PubMed hits based on the search terms including "depression" and the receptor as of August 25, 2016. N.B. 5-HT1D, 1E, 1F, 3B, and 5B are not included in the chart owing to a lack of published research concerning the role of these receptors in behavior.

5-HT, serotonin; KO, knockout; SSRI, selective serotonin reuptake inhibitor.

differences can help clarify the often confusing and sometimes contradictory findings from various preclinical approaches. From a behavioral perspective, these phenotypes can be segmented through formal unsupervised factor analyses to better divide depressive behaviors into meaningful endophenotypes. Then predictors of the different endophenotypes could be tested by including genetic or pharmacological manipulations.

\section{5- $\mathrm{HT}_{1 \mathrm{~A}}$ and depression}

Of the 15 known serotonin receptors, the $5-\mathrm{HT}_{1 \mathrm{~A}}$ receptor is the most studied for its role in depression ${ }^{39}$. Quantification of 5-HT ${ }_{1 \mathrm{~A}}$ receptor levels in humans from post mortem and positron emission tomography (PET) imaging studies reveals an increased level of $5-\mathrm{HT}_{1 \mathrm{~A}}$ receptors in patients diagnosed with $\mathrm{MDD}^{40-42}$. Gene association studies have linked a polymorphism in the 5- $\mathrm{HT}_{1 \mathrm{~A}}$ regulatory region (rs6295; G-1019C) with receptor levels in the brain and also to increased risk for depression ${ }^{43-47}$. The GG genotype at this single nucleotide polymorphism (SNP) is associated with altered levels of 5-HT $\mathrm{HA}_{1 \mathrm{~A}}$ receptor expression and reduced responsiveness to antidepressant treatment ${ }^{43,48}$. Additionally, clinical studies have revealed antidepressant effects of buspirone and other $5-\mathrm{HT}_{1 \mathrm{~A}}$ receptor agonists ${ }^{49,50}$.

Rodent models have also shown that $5-\mathrm{HT}_{1 \mathrm{~A}}$ receptor agonists, such as 8-hydroxy-2-(di-n-propylamino) tetralin (8-OH-DPAT), can have acute antidepressant-like effects ${ }^{51-53}$. These effects are blocked by $5-\mathrm{HT}_{1 \mathrm{~A}}$ receptor antagonists, suggesting that the antidepressant-like response is specific to $5-\mathrm{HT}_{1 \mathrm{~A}}$ receptor signaling ${ }^{54}$. 5- $\mathrm{HT}_{1 \mathrm{~A}}$ heteroreceptors, expressed throughout the limbic system, are the likely site of action for these acute 5-HT receptor-mediated effects ${ }^{50,55}$. On the other hand, 5-HT ${ }_{1 \mathrm{~A}}$ autoreceptors work in opposition to the heteroreceptors, leading to pro-depressive effects. Specifically, activation results in hyperpolarization and reduced firing of raphe neurons, leading to diminished serotonin release in projection regions ${ }^{56}$. Therefore, stimulation of 5-HT $1 \mathrm{~A}$ autoreceptors from increased extracellular 


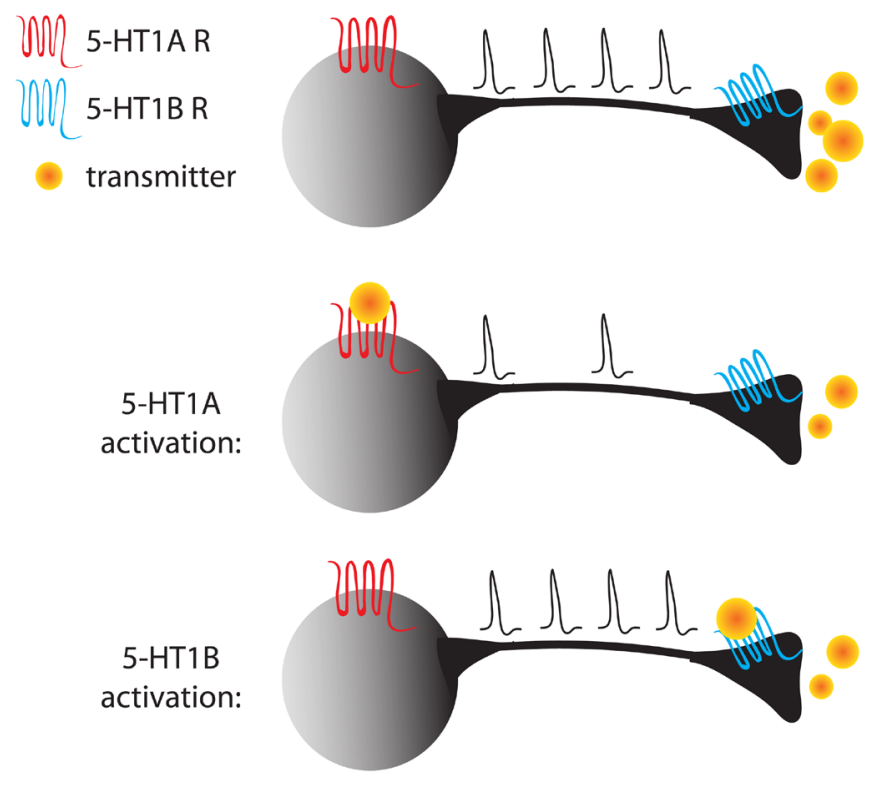

Figure 1. Schematic illustrating the inhibitory effects of serotonin (5-hydroxytryptamine, 5-HT) 1A (5-HT $\left.{ }_{1 \mathrm{~A}}\right)$ (red) and 5-HT ${ }_{1 \mathrm{~B}}(\mathrm{blue})$ receptors on the normal firing and neurotransmitter release of a neuron (top). Activation of $5-\mathrm{HT}_{1 \mathrm{~A}}$ receptors results in decreased firing (middle), while activation of $5-\mathrm{HT}_{1 \mathrm{~B}}$ receptors causes decreased neurotransmitter release through actions in the presynaptic terminal (bottom).

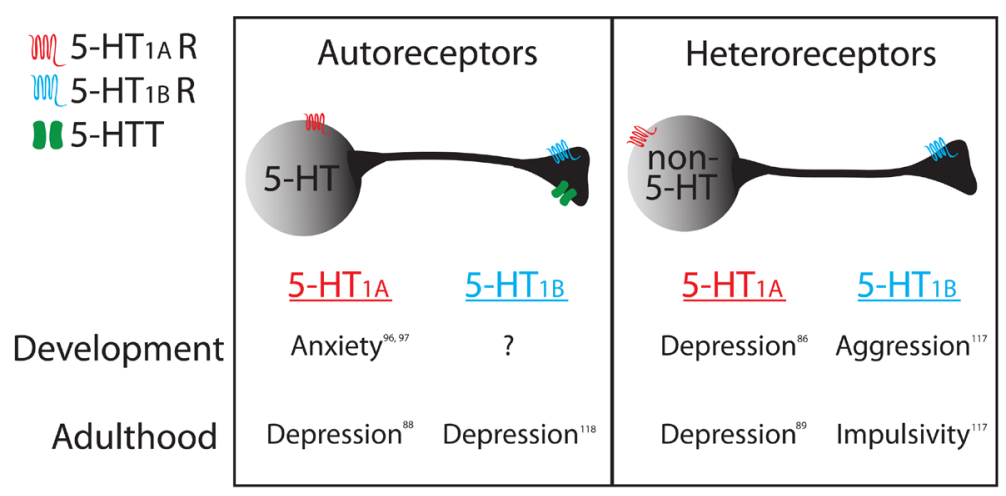

Figure 2. Diagram summarizing the roles of autoreceptor and heteroreceptor populations of serotonin (5-hydroxytryptamine, 5-HT) $1 \mathrm{~A}\left(5-\mathrm{HT}_{1 \mathrm{~A}}\right)$ and $5-\mathrm{HT}_{1 \mathrm{~B}}$ receptors on behavior during development and adulthood. 5- $\mathrm{HTT}$, serotonin transporter.

serotonin following SSRI treatment is thought to oppose SSRI actions by downregulating serotonin neuron activity ${ }^{57}$. Over the first few weeks of treatment, these receptors desensitize, which may underlie the delayed behavioral efficacy of SSRI ${ }^{58}$. Therefore, blocking $5-\mathrm{HT}_{1 \mathrm{~A}}$ autoreceptor activation has been introduced as an adjunctive therapy to SSRIs. 5-HT $1 \mathrm{~A}$ receptor partial agonists such as pindolol, and more recently vilazodone, have been shown to be an effective adjunctive therapy to SSRIs in clinical studies ${ }^{59-62}$. The development of new agonists that preferentially target subpopulations of 5-HT $1 \mathrm{~A}$ receptors, for example autoreceptors versus heteroreceptors, potentially through biased agonism, may be useful tools for the treatment of $\mathrm{MDD}^{63}$.
Differences in receptor levels have also been modeled in mice by using genetic loss-of-function models and have allowed causal links between receptor expression levels and depressive-like behavior. $5-\mathrm{HT}_{1 \mathrm{~A}}$ receptor KO mice have an anti-depressive phenotype ${ }^{64,65}$. Tissue-specific KOs have been especially valuable for the dissection of this phenotype and have allowed investigations into the distinct roles of different populations of receptors ${ }^{66}$. The absence of heteroreceptors results in increased depressive-like behavior- as measured in the forced swim test. This mouse model also allowed for temporal control of receptor expression, which revealed a developmental sensitive period for the effect of heteroreceptors on depressive-like behavior. Specifically, knockdown of 5-HT 
heteroreceptors in adulthood was not sufficient to produce the depressive-like behavior. On the other hand, reduction of autoreceptors in adulthood increased mobility in the forced swim test, suggesting an "anti-depressed" phenotype.

Preclinical studies have also confirmed a causal role for alterations in $5-\mathrm{HT}_{1 \mathrm{~A}}$ receptor expression in antidepressant efficacy. 5-HT receptor $\mathrm{KO}$ mice do not show a behavioral response to fluoxetine ${ }^{67}$. As expected from the pharmacology work, this effect is not mediated by autoreceptors, since reduced expression of $5-\mathrm{HT}_{1 \mathrm{~A}}$ autoreceptors actually increases the speed and efficacy of SSRI response, requiring only 8 days of fluoxetine treatment to show a behavioral antidepressant-like response ${ }^{68}$. Recent data show that $5-\mathrm{HT}_{1 \mathrm{~A}}$ heteroreceptors are critical for an effective behavioral response to an SSRI in mice ${ }^{69}$. Genetic or viral deletion of $5-\mathrm{HT}_{1 \mathrm{~A}}$ receptors specifically in the dentate gyrus of the hippocampus reduced the behavioral response to fluoxetine. Furthermore, expression of $5-\mathrm{HT}_{1 \mathrm{~A}}$ receptors only in the dentate gyrus was sufficient for normal antidepressant-like responses. These results importantly demonstrate a mechanism for 5-HT $\mathrm{HA}_{\mathrm{A}}$-mediated antidepressant effects localized in the mature granule cells of the dentate gyrus.

\section{5-HT ${ }_{1 \mathrm{~A}}$ and other psychiatric-relevant phenotypes}

Anxiety behavior is also modulated strongly by the 5- $\mathrm{HT}_{1 \mathrm{~A}}$ receptor, and, among depressed patients, almost half have a comorbid anxiety disorder ${ }^{70}$. In preclinical studies, $5-\mathrm{HT}_{1 \mathrm{~A}}$ receptor agonists have anxiolytic effects, and $5-\mathrm{HT}_{1 \mathrm{~A}}$ receptor $\mathrm{KO}$ mice display increased anxiety-like behavior ${ }^{64,65,71,72}$. The effect has a developmental sensitive period, since early developmental but not adult rescue of the receptor was sufficient to restore the normal phenotype in the $\mathrm{KO}^{73}$. Consistent with this, early postnatal blockade of $5-\mathrm{HT}_{1 \mathrm{~A}}$ receptors, through genetic or pharmacological methods, also leads to increased anxiety ${ }^{747}$. Recent work has shown that the sensitive period is peri-pubertal, and tissue-specific KO mice point to a role for autoreceptors during this period of development ${ }^{66,76,77}$.

Other psychiatric disorders have also been linked to the 5-HT receptor, including bipolar disorder and post-traumatic stress disorder $^{78,79}$. Additionally, the SNP rs6295 found in the premotor region that is associated with risk for depression is also linked with psychiatric hospitalization, a history of substance abuse, and prior suicide attempts ${ }^{43}$. Consistent with the studies in depression, the $\mathrm{G}$ allele is associated with reduced expression of the 5-HT ${ }_{1 \mathrm{~A}}$ receptor in the prefrontal cortex and an increased risk for psychiatric outcomes. Interestingly, the effects on receptor expression were also seen in the brain during early human embryonic development, suggesting its potential importance in mediating developmental contributions to adult depression. Finally, there were associations with childhood maltreatment with trends towards significant genotype by environment interactions ${ }^{40}$.

\section{5- $\mathrm{HT}_{1 \mathrm{~B}}$ and depression}

While the $5-\mathrm{HT}_{1 \mathrm{~B}}$ receptor is best known for its role in regulating aggressive and impulsive behavior, it also plays an important role in modulating depression. Activation of the $5-\mathrm{HT}_{1 \mathrm{~B}}$ receptor decreases serotonin levels in the brain through effects on release, synthesis, and reuptake ${ }^{33,80,81}$. In humans, reduced $5-\mathrm{HT}_{1 \mathrm{~B}}$ receptor function is associated with $\mathrm{MDD}^{82}$. Additionally, patients with MDD are less responsive to $5-\mathrm{HT}_{1 \mathrm{~B}}$ receptor agonists, suggesting reduced expression or desensitization ${ }^{83,84}$. This is consistent with clinical studies showing that $5-\mathrm{HT}_{1 \mathrm{~B}}$ receptor agonists produce antidepressant effects in humans ${ }^{85-87}$. This has also been shown in mice, with specific agonists resulting in antidepressant-like behavior $^{88,89}$. However, genetic $\mathrm{KO}$ of the receptor also results in antidepressant-like behavior, suggesting that this is possibly caused by compensatory effects ${ }^{90-94}$.

Both autoreceptor and heteroreceptor populations of $5-\mathrm{HT}_{1 \mathrm{~B}}$ receptors have been implicated in depressive-like behaviors using rodent models. However, since $5-\mathrm{HT}_{1 \mathrm{~B}}$ receptors are located on presynaptic terminals, heteroreceptors and autoreceptors have overlapping localization ${ }^{95}$. This rules out brain imaging and pharmacological manipulations in preclinical models as tools to differentiate the role of the two populations of receptors. Therefore, it has been only the recent availability of a tissue-specific genetic mouse model that has allowed the dissection of the role of $5-\mathrm{HT}_{1 \mathrm{~B}}$ receptors in the regulation of behavior ${ }^{96}$.

Our recent studies show that selective ablation of $5-\mathrm{HT}_{1 \mathrm{~B}}$ autoreceptors results in decreased depressive-like behaviors in mice ${ }^{97}$. These mice also show increased elevations in serotonin levels compared to controls following SSRI administration, suggesting a potential mechanism of action for the behavioral effects. Specifically, removing the terminal auto-inhibition may result in increased serotonin in projection regions that are relevant to depressive behavior. Furthermore, we also showed that the impact of 5- $\mathrm{HT}_{1 \mathrm{~B}}$ autoreceptors on behavior was not due to developmental expression, since the phenotype was not recapitulated in a mouse with developmental knockdown. These data are consistent with other evidence suggesting a pro-depressive role for the activation of 5-HT ${ }_{1 \mathrm{~B}}$ autoreceptors ${ }^{98,99}$. For example, 5- $\mathrm{HT}_{1 \mathrm{~B}}$ mRNA is elevated in the raphe of rats following stress and in models of depression such as learned helplessness, and viral overexpression of 5- $\mathrm{HT}_{1 \mathrm{~B}}$ receptors in the raphe results in depressive-like behavior following stress ${ }^{100}$. In rats, reductions in $5-\mathrm{HT}_{1 \mathrm{~B}}$ receptor mRNA in the raphe are seen following SSRI treatment in post mortem brains ${ }^{101,102}$. This effect isn't seen in other brain regions such as the cortex, hippocampus, or striatum, suggesting that this effect is specific to autoreceptors. Additionally, another study showed that $5-\mathrm{HT}_{1 \mathrm{~B}}$ autoreceptors may desensitize following SSRI treatment, similar to 5-HT ${ }_{1 \mathrm{~A}}$ autoreceptors ${ }^{103}$. Finally, a recent PET study in humans reported that following effective cognitive behavioral therapy for depression, $5-\mathrm{HT}_{1 \mathrm{~B}}$ receptor binding was reduced in the brainstem ${ }^{104}$.

There is evidence which suggests an opposing role for $5-\mathrm{HT}_{1 \mathrm{~B}}$ heteroreceptors in depressive behaviors. Activation of $5-\mathrm{HT}_{1 \mathrm{~B}}$ heteroreceptors in a rodent serotonin depletion model (to remove the contribution of autoreceptors) results in an antidepressant-like effect $^{105}$. Additionally, reduced expression of 5-HT ${ }_{1 \mathrm{~B}}$ heteroreceptors in the ventral striatum is associated with depression in humans ${ }^{82}$. Finally, 5- $\mathrm{HT}_{1 \mathrm{~B}}$ receptors located in the ventral striatum have been suggested to interact with p11 (a 5-HT ${ }_{1 \mathrm{~B}}$ receptor-binding protein) to affect depression-related behaviors ${ }^{106,107}$.

\section{5- $\mathrm{HT}_{1 \mathrm{~B}}$ and other psychiatric-related phenotypes}

Reward dysfunction is a major symptom of MDD which is mediated, in part, by altered signaling in the mesolimbic reward system $^{108-112}$. 5-HT ${ }_{1 \mathrm{~B}}$ receptors have been implicated in the neural 
basis of dysregulated reward sensitivity in a number of human studies and preclinical models ${ }^{113-116}$, and both $5-\mathrm{HT}_{1 \mathrm{~B}}$ receptor protein and mRNA are located within the mesolimbic pathway in the nucleus accumbens (NAc) and ventral tegmental area $(\mathrm{VTA})^{95}$. Additionally, activation of $5-\mathrm{HT}_{1 \mathrm{~B}}$ receptors in the VTA increases dopamine levels in the NAc, potentially via effects on GABAergic signaling in the VTA ${ }^{117}$.

Many studies linking the receptor to functional deficits in reward processing have focused on addiction. Polymorphisms in the $5-\mathrm{HT}_{1 \mathrm{~B}}$ receptor gene have also been associated with drug and alcohol abuse ${ }^{118-120}$. Additionally, a PET imaging study revealed increased 5-HT ${ }_{1 \mathrm{~B}}$ receptor binding in pathological gamblers, who have known deficits in reward sensitivity, and gambling disorder is highly comorbid with depression and alcohol and substance use disorders ${ }^{116,121}$. Another PET imaging study shows that there is reduced $5-\mathrm{HT}_{1 \mathrm{~B}}$ receptor binding in cocaine-dependent participants compared to in healthy controls ${ }^{122}$. In preclinical models, 5- $\mathrm{HT}_{1 \mathrm{~B}}$ receptor $\mathrm{KO}$ mice are more motivated to self-administer cocaine ${ }^{123}$. Consistent with this, 5- $\mathrm{HT}_{1 \mathrm{~B}}$ receptor agonists attenuate the motivation for cocaine but paradoxically increase the rewarding effects of cocaine ${ }^{124}$. These effects are mediated by $5-\mathrm{HT}_{1 \mathrm{~B}}$ receptor expression on medium spiny neurons in the NAc, likely through their projections to the $\mathrm{VTA}^{125,126}$. Additionally, 5- $\mathrm{HT}_{1 \mathrm{~B}}$ receptors are required for the rewarding properties of social interaction, supporting an impact on general reward systems ${ }^{114}$.

$5-\mathrm{HT}_{1 \mathrm{~B}}$ receptors are also implicated in impulsive aggression. In humans, polymorphisms in the gene encoding 5-HT $\mathrm{H}_{1 \mathrm{~B}}$ receptors have been associated with aggression, suicide, and disorders that include impulsivity as a core phenotype, including attention deficit hyperactivity disorder and substance use disorder ${ }^{15,120,127}$. In mice, $5-\mathrm{HT}_{1 \mathrm{~B}}$ receptor $\mathrm{KOs}$ are highly aggressive in tests of male and female aggression and also display increased impulsivity ${ }^{128-130}$. Additionally, 5-HT ${ }_{1 \mathrm{~B}}$ receptor agonists are known as "serenics" because they decrease aggression" 131 . While the aggressive and impulsive phenotype was originally thought to be modulated by the same underlying circuits, our recent work shows that distinct populations of $5-\mathrm{HT}_{1 \mathrm{~B}}$ receptors modulate aggression and impulsivity ${ }^{96}$. Furthermore, developmental expression of the $5-\mathrm{HT}_{1 \mathrm{~B}}$ receptor influences aggression, while adult expression modulates impulsive behavior.

\section{Conclusion}

There is a considerable body of research that implicates serotonin in the modulation of depression and depression-related behaviors.
The preclinical work delineating the effects of signaling through the $5-\mathrm{HT}_{1 \mathrm{~A}}$ and $5-\mathrm{HT}_{1 \mathrm{~B}}$ receptors has been made possible because of careful pharmacological studies as well as the development of transgenic mouse models that have allowed for tissue-specific and inducible knockdown. These studies have highlighted the complexity of serotonin receptors, showing that their role varies through the lifespan and by cell-type population. Additionally, the availability of specific radioligands for PET imaging of these receptors has allowed for the translation of findings from preclinical work to humans. The large number of studies concerning the role of these receptors is partially due to the fact that the 5-HT 1 receptor subtypes were some of the first discovered, and it may be only a matter of time before the roles of more newly discovered receptors are clarified ${ }^{17}$.

Despite the amassing of evidence of serotonin receptor-specific involvement in depression, the primary pharmaceutical treatment strategy for depression remains the inhibition of serotonin reuptake. The lack of new treatment options is surprising given the need for them, since current SSRI treatments are ineffective in one-third of patients ${ }^{132}$. Additionally, the majority of patients, as seen in the STAR*D study, don't respond to administration of the first SSRI treatment, requiring multi-step treatment plans that take months ${ }^{132}$. Furthermore, the considerable differences in treatment outcome also emphasize the heterogeneity of the depressed patient population. A better understanding of receptor signaling andneural circuit mechanisms by which serotonin affects depression may inform the development of novel, more targeted drugs that influence specific receptors, signaling cascades, or time periods. Also, personalized treatment plans could be developed based on symptoms, biomarkers, or pathophysiological presentation.

\section{Competing interests}

The authors declare that they have no competing interests.

\section{Grant information}

Support for René Hen was provided by Hope for Depression Research Foundation (RGA 13-003), NIH R37MH068542, and R01MH083862. Funding for Katherine Nautiyal was provided by NIH K99 MH106731 and a NARSAD Young Investigator Award.

The funders had no role in study design, data collection and analysis, decision to publish, or preparation of the manuscript.
1. Coppen A: The biochemistry of affective disorders. Br J Psychiatry. 1967 113(504): 1237-64.

PubMed Abstract | Publisher Full Text

2. Albert PR, Benkelfat C: The neurobiology of depression--revisiting the serotonin hypothesis. II. Genetic, epigenetic and clinical studies. Philos Trans $R$ Soc Lond B Biol Sci. 2013; 368(1615): 20120535. PubMed Abstract | Publisher Full Text | Free Full Text
3. De Montigny C: Enhancement of the $5-\mathrm{HT}$ neurotransmission by antidepressant treatments. J Physiol (Paris). 1981; 77(2-3): 455-61. PubMed Abstract

4. AZIMA H, VISPO RH: Imipramine; a potent new anti-depressant compound. $A m$ J Psychiatry. 1958; 115(3): 245-6. PubMed Abstract | Publisher Full Text

5. Messing RB, Phebus L, Fisher LA, et al.: Analgesic effect of fluoxetine 
hydrochloride (Lilly 110140), a specific inhibitor of serotonin uptake. Psychopharmacol Commun. 1975; 1(5): 511-21. PubMed Abstract

6. de Montigny C, Blier P: Effects of antidepressant treatments on 5-HT neurotransmission: electrophysiological and clinical studies. Adv Biochem Psychopharmacol. 1984; 39: 223-39. PubMed Abstract

7. Lemberger L, Rowe H, Carmichael R, et al:: Pharmacologic effects in man of a specific serotonin-reuptake inhibitor. Science. 1978; 199(4327): 436-7. PubMed Abstract | Publisher Full Text

8. F Nackenoff AG, Moussa-Tooks AB, McMeekin AM, et al:: Essentia Contributions of Serotonin Transporter Inhibition to the Acute and Chronic Actions of Fluoxetine and Citalopram in the SERT Met172 Mouse. Neuropsychopharmacology. 2016; 41(7): 1733-41.

PubMed Abstract | Publisher Full Text | Free Full Text | F1000 Recommendation

9. Asberg M, Mårtensson B: Serotonin selective antidepressant drugs: past, present, future. Clin Neuropharmacol. 1993; 16 Suppl 3: S32-44. PubMed Abstract

10. Mann JJ, McBride PA, Anderson GM, et al:: Platelet and whole blood serotonin content in depressed inpatients: correlations with acute and life-time psychopathology. Biol Psychiatry. 1992; 32(3): 243-57. PubMed Abstract | Publisher Full Text

11. Coppen A, Turner P, Rowsell AR, et al.: 5-Hydroxytryptamine (5-HT) in the wholeblood of patients with depressive illness. Postgrad Med J. 1976; 52(605): 156-8. PubMed Abstract | Publisher Full Text | Free Full Text

12. van Praag $\mathrm{HM}$, de Haan $\mathrm{S}$ : Central serotonin metabolism and frequency of depression. Psychiatry Res. 1979; 1(3): 219-24. PubMed Abstract | Publisher Full Text

13. Asberg M, Bertilsson L, Mårtensson $\mathrm{B}$, et al.: CSF monoamine metabolites in melancholia. Acta Psychiatr Scand. 1984; 69(3): 201-19. PubMed Abstract | Publisher Full Text

14. Karege F, Widmer J, Bovier $P$, et al.: Platelet serotonin and plasma tryptophan in depressed patients: effect of drug treatment and clinical outcome. Neuropsychopharmacology. 1994; 10(3): 207-14 PubMed Abstract | Publisher Full Text

15. Ogawa S, Fujii T, Koga N, et al:: Plasma L-tryptophan concentration in major depressive disorder: new data and meta-analysis. J Clin Psychiatry. 2014; 75(9): e906-15.

PubMed Abstract | Publisher Full Tex

16. Gaspar $\mathrm{P}, \mathrm{Cases} \mathrm{O}$, Maroteaux $\mathrm{L}$ : The developmental role of serotonin: news from mouse molecular genetics. Nat Rev Neurosci. 2003; 4(12): 1002-12. PubMed Abstract | Publisher Full Text

17. Barnes NM, Sharp T: A review of central 5-HT receptors and their function. Neuropharmacology. 1999; 38(8): 1083-152. PubMed Abstract | Publisher Full Text

18. Bang SJ, Jensen P, Dymecki SM, et al.: Projections and interconnections of genetically defined serotonin neurons in mice. Eur J Neurosci. 2012; 35(1): $85-96$.

PubMed Abstract | Publisher Full Text | Free Full Text

19. Carr GV, Lucki I: The role of serotonin receptor subtypes in treating depression: a review of animal studies. Psychopharmacology (Berl). 2011; 213(2-3): 265-87. PubMed Abstract | Publisher Full Text | Free Full Text

20. F Caspi A, Sugden K, Moffitt TE, et al: Influence of life stress on depression: moderation by a polymorphism in the 5-HTT gene. Science. 2003; 301(5631): $386-9$.

PubMed Abstract | Publisher Full Text | F1000 Recommendation

21. $\mathrm{F}$ Karg K, Burmeister M, Shedden $\mathrm{K}$, et al:: The serotonin transporter promote variant (5-HTTLPR), stress, and depression meta-analysis revisited: evidence of genetic moderation. Arch Gen Psychiatry. 2011; 68(5): 444-54 PubMed Abstract | Publisher Full Text | Free Full Text | F1000 Recommendation

22. F Risch N, Herrell R, Lehner T, et al.: Interaction between the serotonin transporter gene (5-HTTLPR), stressful life events, and risk of depression: a meta-analysis. JAMA. 2009; 301(23): 2462-71.

PubMed Abstract | Publisher Full Text | Free Full Text | F1000 Recommendation

23. F Pezawas L, Meyer-Lindenberg A, Drabant EM, et al:: 5-HTTLPR polymorphism impacts human cingulate-amygdala interactions: a genetic susceptibility mechanism for depression. Nat Neurosci. 2005; 8(6): 828-34. PubMed Abstract | Publisher Full Text | F1000 Recommendation

24. F Ansorge MS, Zhou M, Lira A, et al.: Early-life blockade of the 5-HT transporter alters emotional behavior in adult mice. Science. 2004; 306(5697): 879-81.

PubMed Abstract | Publisher Full Text | F1000 Recommendation

25. Albert PR, Robillard L: G protein specificity: traffic direction required. Cell Signal. 2002; 14(5): 407-18. PubMed Abstract | Publisher Full Text

26. Laporte AM, Lima L, Gozlan $\mathrm{H}$, et al.: Selective in vivo labelling of brain 5-HT receptors by $\left[{ }^{3} \mathrm{H}\right]$ WAY 100635 in the mouse. Eur J Pharmacol. 1994; 271(2-3): 505-14.

PubMed Abstract | Publisher Full Text
27. Boschert U, Amara DA, Segu L, et al.: The mouse 5-hydroxytryptamine ${ }_{1 \mathrm{~B}}$ receptor is localized predominantly on axon terminals. Neuroscience. 1994; 58(1): 167-82. PubMed Abstract | Publisher Full Text

28. Ghavami A, Stark KL, Jareb M, et al:: Differential addressing of 5-HT1A and 5-HT1B receptors in epithelial cells and neurons. J Cell Sci. 1999; 112(Pt 6) 967-76.

PubMed Abstract

29. Riad M, Garcia S, Watkins KC, et al:: Somatodendritic localization of 5-HT1A and preterminal axonal localization of 5-HT1B serotonin receptors in adult rat brain. J Comp Neurol. 2000; 417(2): 181-94.

PubMed Abstract | Publisher Full Text

30. Beck SG, Choi KC, List TJ: Comparison of 5-hydroxytryptamine1A-mediated hyperpolarization in CA1 and CA3 hippocampal pyramidal cells. $J$ Pharmacol Exp Ther. 1992; 263(1): 350-9.

PubMed Abstract

31. Knobelman DA, Kung HF, Lucki I: Regulation of extracellular concentrations of 5 -hydroxytryptamine (5-HT) in mouse striatum by $5-\mathrm{HT}_{1 \mathrm{~A}}$ and $5-\mathrm{HT}_{1 \mathrm{~B}}$ receptors. $J$ Pharmacol Exp Ther. 2000; 292(3): 1111-7.

PubMed Abstract

32. Mizutani $\mathrm{H}$, Hori $\mathrm{T}$, Takahashi $\mathrm{T}$ : $5-\mathrm{HT}_{18}$ receptor-mediated presynaptic inhibition at the calyx of Held of immature rats. Eur J Neurosci. 2006; 24(7): 1946-54. PubMed Abstract | Publisher Full Tex

33. Hagan CE, McDevitt RA, Liu Y, et al:: 5-HT autoreceptor regulation of serotonin transporter activity in synaptosomes. Synapse. 2012; 66(12): 1024-34. PubMed Abstract | Publisher Full Text | Free Full Text

34. $\mathrm{F}$ Montanez S, Munn JL, Owens WA, et al:: $\mathbf{5}-\mathrm{HT}_{1 \mathrm{~B}}$ receptor modulation of the serotonin transporter in vivo: studies using $\mathrm{KO}$ mice. Neurochem Int. 2014; 73 $127-31$.

PubMed Abstract | Publisher Full Text | Free Full Text | F1000 Recommendation

35. Clark MS, McDevitt RA, Neumaier JF: Quantitative mapping of tryptophan hydroxylase-2, $5-\mathrm{HT}_{1 \mathrm{~A}}, 5-\mathrm{HT}_{1 \mathrm{~B}}$, and serotonin transporter expression across the anteroposterior axis of the rat dorsal and median raphe nuclei. J Comp Neurol. 2006; 498(5): 611-23.

PubMed Abstract | Publisher Full Tex

36. Maroteaux L, Saudou F, Amlaiky N, et al:: Mouse 5HT1B serotonin receptor: cloning, functional expression, and localization in motor control centers. Proc Natl Acad Sci U S A. 1992; 89(7): 3020-4.

PubMed Abstract | Publisher Full Text | Free Full Text

37. Pompeiano M, Palacios JM, Mengod G: Distribution and cellular localization of mRNA coding for 5-HT1A receptor in the rat brain: correlation with receptor binding. J Neurosci. 1992; 12(2): 440-53.

PubMed Abstract

38. Donaldson ZR, Hen R: From psychiatric disorders to animal models: a bidirectional and dimensional approach. Biol Psychiatry. 2015; 77(1): 15-21. PubMed Abstract | Publisher Full Text | Free Full Text

39. Savitz J, Lucki I, Drevets WC: $\mathbf{5 - H T}$ receptor function in major depressive disorder. Prog Neurobiol. 2009; 88(1): 17-31. PubMed Abstract | Publisher Full Text | Free Full Text

40. F Parsey RV, Ogden RT, Miller JM, et al:: Higher serotonin 1A binding in a second major depression cohort: modeling and reference region considerations. Biol Psychiatry. 2010; 68(2): 170-8. PubMed Abstract | Publisher Full Text | Free Full Text | F1000 Recommendation

41. F Kaufman J, Sullivan GM, Yang J, et al:: Quantification of the Serotonin 1A Receptor Using PET: Identification of a Potential Biomarker of Major Depression in Males. Neuropsychopharmacology. 2015; 40(7): 1692-9. PubMed Abstract | Publisher Full Text | Free Full Text | F1000 Recommendation

42. Stockmeier CA, Shapiro LA, Dilley GE, et al:: Increase in serotonin-1A autoreceptors in the midbrain of suicide victims with major depressionpostmortem evidence for decreased serotonin activity. J Neurosci. 1998; 18(18): 7394-401. PubMed Abstract

43. Donaldson ZR, Le Francois B, Santos TL, et al:: The functional serotonin 1a receptor promoter polymorphism, rs6295, is associated with psychiatric illness and differences in transcription. Transl Psychiatry. 2016; 6: e746. PubMed Abstract | Publisher Full Text | Free Full Text

44. Albert PR, Lemonde S: 5-HT1A receptors, gene repression, and depression: guilt by association. Neuroscientist. 2004; 10(6): 575-93. PubMed Abstract | Publisher Full Text

45. Albert PR: Transcriptional regulation of the $5-\mathrm{HT}_{1 \mathrm{~A}}$ receptor: implications fo mental illness. Philos Trans R Soc Lond B Biol Sci. 2012; 367(1601): 2402-15. PubMed Abstract | Publisher Full Text | Free Full Text

46. Strobel A, Gutknecht L, Rothe C, et al:: Allelic variation in $\mathbf{5 - H T}$, receptor expression is associated with anxiety- and depression-related personality traits. J Neural Transm (Vienna). 2003; 110(12): 1445-53. PubMed Abstract | Publisher Full Text

47. F Lemonde S, Turecki G, Bakish D, et al:: Impaired repression at a 5-hydroxytryptamine 1A receptor gene polymorphism associated with major depression and suicide. J Neurosci. 2003; 23(25): 8788-99. PubMed Abstract | F1000 Recommendation

48. Parsey RV, Olvet DM, Oquendo MA, et al:: Higher $5-\mathrm{HT}_{1 \mathrm{~A}}$ receptor binding potential 
during a major depressive episode predicts poor treatment response: preliminary data from a naturalistic study. Neuropsychopharmacology. 2006; 31(8): 1745-9.

PubMed Abstract | Publisher Full Text

49. Robinson DS, Rickels K, Feighner J, et al.: Clinical effects of the 5-HT1A partial agonists in depression: a composite analysis of buspirone in the treatment of depression. J Clin Psychopharmacol. 1990; 10(3 Suppl): 67S-76S. PubMed Abstract

50. Lucki I: Behavioral studies of serotonin receptor agonists as antidepressant drugs. J Clin Psychiatry. 1991; 52 Suppl: 24-31. PubMed Abstract

51. Kennett GA, Dourish CT, Curzon G: Antidepressant-like action of 5-HT agonists and conventional antidepressants in an animal model of depression. agonists and conventional antidepres
Eur J Pharmacol. 1987; 134(3): 265-74. PubMed Abstract | Publisher Full Text

52. Detke MJ, Rickels M, Lucki I: Active behaviors in the rat forced swimming test differentially produced by serotonergic and noradrenergic antidepressants. Psychopharmacology (Berl). 1995; 121(1): 66-72. PubMed Abstract | Publisher Full Text

53. López-Rubalcava C, Lucki I: Strain differences in the behavioral effects of antidepressant drugs in the rat forced swimming test. Neuropsychopharmacology. 2000; 22(2): 191-9

PubMed Abstract | Publisher Full Text

54. Detke MJ, Wieland S, Lucki I: Blockade of the antidepressant-like effects of 8-OH-DPAT, buspirone and desipramine in the rat forced swim test by $5 \mathrm{HT}_{1 \mathrm{~A}}$ receptor antagonists. Psychopharmacology (Berl). 1995; 119(1): 47-54. PubMled Abstract | Publisher Full Text

55. Blier $\mathrm{P}$, de Montigny $\mathrm{C}$ : Current advances and trends in the treatment of depression. Trends Pharmacol Sci. 1994; 15(7): 220-6. PubMed Abstract | Publisher Full Text

56. Albert PR, Lembo P, Storring JM, et al:: The 5-HT1A receptor: signaling, desensitization, and gene transcription. Neuropsychopharmacology. 1996; 14(1): $19-25$.

PubMed Abstract | Publisher Full Text

57. Blier $\mathrm{P}$, Ward NM: Is there a role for $5-\mathrm{HT}_{1 \mathrm{~A}}$ agonists in the treatment of depression? Biol Psychiatry. 2003; 53(3): 193-203.

PubMed Abstract | Publisher Full Text

58. Blier P, Piñeyro G, el Mansari M, et al.: Role of somatodendritic 5-HT autoreceptors in modulating 5-HT neurotransmission. Ann N Y Acad Sci. 1998; 861: 204-16.

PubMed Abstract | Publisher Full Text

59. Tome MB, Isaac MT, Harte R, et al.: Paroxetine and pindolol: a randomized trial of serotonergic autoreceptor blockade in the reduction of antidepressant latency. Int Clin Psychopharmacol. 1997; 12(2): 81-9. PubMed Abstract

60. Artigas $F$, Celada $P$, Laruelle $M$, et al.: How does pindolol improve antidepressant action? Trends Pharmacol Sci. 2001; 22(5): 224-8. PubMed Abstract | Publisher Full Text

61. Sahli ZT, Banerjee P, Tarazi FI: The Preclinical and Clinical Effects of Vilazodone for the Treatment of Major Depressive Disorder. Expert Opin Drug Discov. 2016; 11(5): 515-23.

PubMed Abstract | Publisher Full Text | Free Full Text

62. Artigas F, Romero L, de Montigny $\mathrm{C}$, et al:: Acceleration of the effect of selected antidepressant drugs in major depression by $5-\mathrm{HT}_{1 \mathrm{~A}}$ antagonists. Trends Neurosci. 1996; 19(9): 378-83.

PubMed Abstract | Publisher Full Tex

63. Newman-Tancredi A, Martel JC, Assié MB, et al:: Signal transduction and functional selectivity of F15599, a preferential post-synaptic 5-HT receptor agonist. Br J Pharmacol. 2009; 156(2): 338-53. PubMed Abstract | Publisher Full Text | Free Full Text

64. Ramboz S, Oosting R, Amara DA, et al.: Serotonin receptor 1A knockout: an animal model of anxiety-related disorder. Proc Natl Acad Sci U S A. 1998; 95(24): 14476-81.

PubMed Abstract | Publisher Full Text | Free Full Text

65. Heisler LK, Chu HM, Brennan TJ, et al:: Elevated anxiety and antidepressant-like responses in serotonin 5-HT , receptor mutant mice. Proc Natl Acad Sci U S A 1998; 95(25): 15049-54

PubMed Abstract | Free Full Text

66. Richardson-Jones JW, Craige CP, Nguyen TH, et al.: Serotonin-1A autoreceptors are necessary and sufficient for the normal formation of circuits underlying innate anxiety. J Neurosci. 2011; 31(16): 6008-18. PubMed Abstract | Publisher Full Text | Free Full Text

67. F Santarelli L, Saxe M, Gross C, et al.: Requirement of hippocampal neurogenesis for the behavioral effects of antidepressants. Science. 2003 301(5634): 805-9.

PubMed Abstract | Publisher Full Text | F1000 Recommendation

68. Richardson-Jones JW, Craige CP, Guiard BP, et al:: $\mathbf{5 - H T}$ autoreceptor levels determine vulnerability to stress and response to antidepressants. Neuron. 2010; 65(1): 40-52.

PubMed Abstract | Publisher Full Text | Free Full Text

69. Samuels BA, Anacker $\mathrm{C}, \mathrm{Hu}$ A, et al:: 5-HT1A receptors on mature dentate gyrus granule cells are critical for the antidepressant response. Nat Neurosci. 2015;
18(11): 1606-16.

PubMed Abstract | Publisher Full Text | Free Full Text

70. Fava M, Rankin MA, Wright EC, et al:: Anxiety disorders in major depression. Compr Psychiatry. 2000; 41(2): 97-102.

PubMed Abstract | Publisher Full Text

71. de Vry J: 5-HT issues. Psychopharmacology (Berl). 1995; 121(1): 1-26. PubMed Abstract | Publisher Full Text

72. Parks $\mathrm{CL}$, Robinson $\mathrm{PS}$, Sibille $\mathrm{E}$, et al.: Increased anxiety of mice lacking the serotonin receptor. Proc Natl Acad Sci U S A. 1998; 95(18): 10734-9. PubMed Abstract | Publisher Full Text | Free Full Text

73. F Gross $\mathrm{C}$, Zhuang $\mathrm{X}$, Stark K, et al.: Serotonin receptor acts during development to establish normal anxiety-like behaviour in the adult. Nature. 2002; 416(6879): 396-400.

PubMed Abstract | Publisher Full Text | F1000 Recommendation

74. Lo lacono L, Gross C: $\boldsymbol{\alpha}-\mathrm{Ca}^{2+} /$ calmodulin-dependent protein kinase II contributes to the developmental programming of anxiety in serotonin receptor 1A knock-out mice. J Neurosci. 2008; 28(24): 6250-7. PubMed Abstract | Publisher Full Text | Free Full Text

75. Vinkers $\mathrm{CH}$, Oosting RS, van Bogaert, et al.: Early-life blockade of 5-HT receptors alters adult anxiety behavior and benzodiazepine sensitivity. BiO Psychiatry. 2010; 67(4): 309-16. PubMed Abstract | Publisher Full Tex

76. F Garcia-Garcia AL, Meng Q, Richardson-Jones J, et al.: Disruption of $5-\mathbf{H T}_{1 \mathrm{~A}}$ function in adolescence but not early adulthood leads to sustained increases of anxiety. Neuroscience. 2016; 321: 210-21.

PubMed Abstract | Publisher Full Text | Free Full Text | F1000 Recommendation

77. Donaldson ZR, Piel DA, Santos TL, et al.: Developmental effects of serotonin 1A autoreceptors on anxiety and social behavior. Neuropsychopharmacology. 2014; 39(2): 291-302.

PubMed Abstract | Publisher Full Text | Free Full Text

78. Sullivan GM, Ogden RT, Huang $\mathrm{Y}$, et al:: Higher in vivo serotonin-1a binding in posttraumatic stress disorder: a PET study with $\left[{ }^{11} \mathrm{C}\right]$ WAY-100635. Depress Anxiety. 2013; 30(3): 197-206.

PubMed Abstract | Publisher Full Text | Free Full Text

79. Sullivan GM, Ogden RT, Oquendo MA, et al:: Positron emission tomography quantification of serotonin-1A receptor binding in medication-free bipolar depression. Biol Psychiatry. 2009; 66(3): 223-30.

PubMed Abstract | Publisher Full Text | Free Full Text

80. Hjorth S, Suchowski CS, Galloway MP: Evidence for 5-HT autoreceptormediated, nerve impulse-independent, control of 5-HT synthesis in the rat brain. Synapse. 1995; 19(3): 170-6.

PubMed Abstract | Publisher Full Text

81. Trillat AC, Malagié I, Scearce $\mathrm{K}$, et al:: Regulation of serotonin release in the frontal cortex and ventral hippocampus of homozygous mice lacking $5-\mathrm{HT}_{1 \mathrm{~B}}$ receptors: in vivo microdialysis studies. J Neurochem. 1997; 69(5): 2019-25. PubMed Abstract | Publisher Full Text

82. Murrough JW, Henry S, Hu J, et al:: Reduced ventral striatal/ventral pallidal serotonin $_{1 \mathrm{~B}}$ receptor binding potential in major depressive disorder. Psychopharmacology (Berl). 2011; 213(2-3): 547-53. PubMed Abstract | Publisher Full Text | Free Full Tex

83. Whale R, Clifford EM, Bhagwagar Z, et al.: Decreased sensitivity of 5-HT receptors in melancholic depression. Br J Psychiatry. 2001; 178(5): 454-7. PubMed Abstract | Publisher Full Text

84. Cleare AJ, Murray RM, Sherwood RA, et al:: Abnormal 5-HT receptor function in major depression: a neuropharmacological challenge study using sumatriptan. Psychol Med. 1998; 28(2): 295-300. PubMed Abstract

85. Stern L, Zohar J, Cohen R, et al:: Treatment of severe, drug resistant obsessive compulsive disorder with the $5 \mathrm{HT}_{10}$ agonist sumatriptan. Eur Neuropsychopharmacol. 1998; 8(4): 325-8. PubMed Abstract | Publisher Full Text

86. Tatarczynska E, Antkiewicz-Michaluk L, Klodzinska A, et al: Antidepressantlike effect of the selective 5-HT receptor agonist CP 94253: a possible mechanism of action. Eur J Pharmacol. 2005; 516(1): 46-50. PubMed Abstract | Publisher Full Text

87. Miranda H, Ortiz G, Figueroa S, et al: Depression scores following migraine treatment in patients attending a specialized center for headache and neurology. Headache. 2001; 41(7): 680-4. PubMed Abstract | Publisher Full Text

88. Redrobe JP, Bourin M: Evidence of the activity of lithium on 5-HT1B receptors in the mouse forced swimming test: comparison with carbamazepine and sodium valproate. Psychopharmacology (Berl). 1999; 141(4): 370-7. PubMed Abstract | Publisher Full Text

89. O'Neill MF, Conway MW: Role of $5-\mathrm{HT}_{1 \mathrm{~A}}$ and $5-\mathrm{HT}_{1 \mathrm{~B}}$ receptors in the mediation of behavior in the forced swim test in mice. Neuropsychopharmacology. 2001; 24(4): 391-8.

PubMed Abstract | Publisher Full Text

90. Knobelman DA, Hen R, Lucki I: Genetic regulation of extracellular serotonin by 5-hydroxytryptamine(1A) and 5-hydroxytryptamine(1B) autoreceptors in different brain regions of the mouse. J Pharmacol Exp Ther. 2001; 298(3): 
1083-91.

PubMed Abstract

91. Malagié I, Trillat AC, Bourin M, et al:: $\mathbf{5}-\mathbf{H T} \mathbf{T}_{18}$ Autoreceptors limit the effects of selective serotonin re-uptake inhibitors in mouse hippocampus and frontal cortex. J Neurochem. 2001; 76(3): 865-71.

PubMed Abstract | Publisher Full Text

92. Jones MD, Lucki I: Sex differences in the regulation of serotonergic transmission and behavior in 5-HT receptor knockout mice. Neuropsychopharmacology. 2005; 30(6): 1039-47. PubMed Abstract | Publisher Full Text

93. Bechtholt AJ, Smith K, Gaughan S, et al: Sucrose intake and fasting glucose levels in 5-HT and 5-HT receptor mutant mice. Physiol Behav. 2008; 93(4-5): 659-65. PubMed Abstract | Publisher Full Text | Free Full Text

94. Mayorga AJ, Dalvi A, Page ME, et al.: Antidepressant-like behavioral effects in 5-hydroxytryptamine(1A) and 5-hydroxytryptamine(1B) receptor mutant mice. J Pharmacol Exp Ther. 2001; 298(3): 1101-7. PubMed Abstract

95. Sari Y: Serotonin ${ }_{1 \mathrm{~B}}$ receptors: from protein to physiological function and behavior. Neurosci Biobehav Rev. 2004; 28(6): 565-82. PubMed Abstract | Publisher Full Text

96. Nautiyal KM, Tanaka KF, Barr MM, et al.: Distinct Circuits Underlie the Effects of 5-HT1B Receptors on Aggression and Impulsivity. Neuron. 2015; 86(3): 813-26. PubMed Abstract | Publisher Full Text | Free Full Text

97. Nautiyal KM, Tritschler L, Ahmari SE, et al:: A Lack of Serotonin 1B Autoreceptors Results in Decreased Anxiety and Depression-Related Behaviors. Neuropsychopharmacology. 2016; 41(12): 2941-50. PubMed Abstract | Publisher Full Text | Free Full Text

98. Neumaier JF, Petty F, Kramer GL, et al.: Learned helplessness increases 5-hydroxytryptamine1B receptor mRNA levels in the rat dorsal raphe nucleus. Biol Psychiatry. 1997; 41(6): 668-74. PubMed Abstract | Publisher Full Text

99. Neumaier JF, Edwards E, Plotsky PM: 5-HT mrna regulation in two animal models of altered stress reactivity. Biol Psychiatry. 2002; 51(11): 902-8. PubMed Abstract | Publisher Full Text

100. Clark MS, Sexton TJ, McClain M, et al.: Overexpression of $5-\mathrm{HT}_{1 \mathrm{~B}}$ receptor in dorsal raphe nucleus using Herpes Simplex Virus gene transfer increases anxiety behavior after inescapable stress. J Neurosci. 2002; 22(11): 4550-62. PubMed Abstract

101. Neumaier JF, Root DC, Hamblin MW: Chronic fluoxetine reduces serotonin transporter mRNA and 5- $\mathrm{HT}_{1 \mathrm{~B}}$ mRNA in a sequential manner in the rat dorsal raphe nucleus. Neuropsychopharmacology. 1996; 15(5): 515-22. PubMed Abstract | Publisher Full Text

102. Anthony JP, Sexton TJ, Neumaier JF: Antidepressant-induced regulation of $5-\mathrm{HT}_{1 \mathrm{~b}}$ mRNA in rat dorsal raphe nucleus reverses rapidly after drug discontinuation. J Neurosci Res. 2000; 61(1): 82-7. PubMed Abstract | Publisher Full Text

103. Davidson C, Stamford JA: Effect of chronic paroxetine treatment on 5-HT ${ }_{18}$ and $5-\mathrm{HT}_{1 \mathrm{D}}$ autoreceptors in rat dorsal raphe nucleus. Neurochem Int. 2000; 36(2): $91-6$.

PubMed Abstract | Publisher Full Text

104. F Tiger M, Rück C, Forsberg A, et al:: Reduced 5-HT receptor binding in the dorsal brain stem after cognitive behavioural therapy of major depressive disorder. Psychiatry Res. 2014; 223(2): 164-70. PubMed Abstract | Publisher Full Text | F1000 Recommendation

105. Chenu F, David DJ, Leroux-Nicollet I, et al.: Serotonin ${ }_{18}$ heteroreceptor activation induces an antidepressant-like effect in mice with an alteration of the serotonergic system. J Psychiatry Neurosci. 2008; 33(6): 541-50. PubMed Abstract | Free Full Text

106. $\mathrm{F}$ Svenningsson $\mathrm{P}$, Chergui $\mathrm{K}$, Rachleff $\mathrm{I}$, et al: Alterations in $5-\mathrm{HT}_{1 \mathrm{~B}}$ receptor function by $\mathrm{p} 11$ in depression-like states. Science. 2006; 311(5757): 77-80. PubMed Abstract | Publisher Full Text | F1000 Recommendation

107. Alexander B, Warner-Schmidt J, Eriksson T, et al: Reversal of depressed behaviors in mice by 111 gene therapy in the nucleus accumbens. Sci Transl Med. 2010; 2(54): 54ra76. PubMed Abstract | Publisher Full Text | Free Full Text

108. Lim BK, Huang KW, Grueter BA, et al.: Anhedonia requires MC4R-mediated synaptic adaptations in nucleus accumbens. Nature. 2012; 487(7406): 183-9. PubMed Abstract | Publisher Full Text | Free Full Text

109. Brown AS, Gershon S: Dopamine and depression. J Neural Transm Gen Sect. 1993; 91(2-3): 75-109. PubMed Abstract | Publisher Full Text

110. D'Aquila PS, Collu M, Gessa GL, et al.: The role of dopamine in the mechanism of action of antidepressant drugs. Eur J Pharmacol. 2000; 405(1-3): 365-73. PubMed Abstract | Publisher Full Text

111. Nestler EJ, Carlezon WA Jr: The mesolimbic dopamine reward circuit in depression. Biol Psychiatry. 2006; 59(12): 1151-9. PubMed Abstract | Publisher Full Text

112. Heshmati M, Russo SJ: Anhedonia and the brain reward circuitry in depression. Curr Behav Neurosci Rep. 2015; 2(3): 146-53. PubMed Abstract | Publisher Full Text | Free Full Text

113. Barot SK, Ferguson SM, Neumaier JF: $\mathbf{5}-\mathrm{HT}_{1 \mathrm{~B}}$ receptors in nucleus accumbens efferents enhance both rewarding and aversive effects of cocaine. Eur $J$
Neurosci. 2007; 25(10): 3125-31.

PubMed Abstract | Publisher Full Text

114. F Dolen G, Darvishzadeh A, Huang KW, et al:: Social reward requires coordinated activity of nucleus accumbens oxytocin and serotonin. Nature. 2013; 501(7466): 179-84.

PubMed Abstract | Publisher Full Text | Free Full Text | F1000 Recommendation

115. Zouk H, McGirr A, Lebel V, et al.: The effect of genetic variation of the serotonin $1 \mathrm{~B}$ receptor gene on impulsive aggressive behavior and suicide. Am J Med Genet B Neuropsychiatr Genet. 2007; 144B(8): 996-1002.

PubMed Abstract | Publisher Full Text

116. Potenza MN, Walderhaug $\mathrm{E}$, Henry $\mathrm{S}$, et al:: Serotonin $1 \mathrm{~B}$ receptor imaging in pathological gambling. World J Biol Psychiatry. 2013; 14(2): 139-45. PubMed Abstract | Publisher Full Text | Free Full Text

117. O'Dell LE, Parsons LH: Serotonin ${ }_{18}$ receptors in the ventral tegmental area modulate cocaine-induced increases in nucleus accumbens dopamine levels. $J$ Pharmacol Exp Ther. 2004; 311(2): 711-9.

PubMed Abstract | Publisher Full Text

118. Contini V, Bertuzzi GP, Polina ER, et al:: A haplotype analysis is consistent with the role of functional HTR1B variants in alcohol dependence. Drug Alcohol Depend. 2012; 122(1-2): 100-4. PubMed Abstract | Publisher Full Tex

119. Proudnikov D, LaForge KS, Hofflich $\mathrm{H}$, et al:: Association analysis of polymorphisms in serotonin 1B receptor (HTR1B) gene with heroin addiction: a comparison of molecular and statistically estimated haplotypes. Pharmacogenet Genomics. 2006; 16(1): 25-36. PubMed Abstract | Publisher Full Text

120. Cao J, LaRocque E, Li D: Associations of the 5-hydroxytryptamine (serotonin) receptor 1B gene (HTR1B) with alcohol, cocaine, and heroin abuse. Am J Med Genet B Neuropsychiatr Genet. 2013; 162B(2): 169-76. PubMed Abstract | Publisher Full Text | Free Full Text

121. Petry NM, Stinson FS, Grant BF: Comorbidity of DSM-IV pathological gambling and other psychiatric disorders: results from the National Epidemiologic Survey on Alcohol and Related Conditions. J Clin Psychiatry. 2005; 66(5): 564-74. PubMed Abstract | Publisher Full Text

122. $F$ Matuskey D, Bhagwagar Z, Planeta B, et al.: Reductions in brain 5-HT receptor availability in primarily cocaine-dependent humans. Biol Psychiatry. 2014; 76(10): 816-22. PubMed Abstract | Publisher Full Text | Free Full Text | F1000 Recommendation

123. Rocha BA, Scearce-Levie K, Lucas JJ, et al.: Increased vulnerability to cocaine in mice lacking the serotonin-1B receptor. Nature. 1998; 393(6681): 175-8. PubMed Abstract | Publisher Full Text

124. Pentkowski NS, Acosta JI, Browning JR, et al.: Stimulation of $5-\mathrm{HT}_{1 \mathrm{~B}}$ receptors enhances cocaine reinforcement yet reduces cocaine-seeking behavior. Addict Biol. 2009; 14(4): 419-30. PubMed Abstract | Publisher Full Text | Free Full Text

125. Neumaier JF, Vincow ES, Arvanitogiannis A, et al:: Elevated expression of 5-HT1B receptors in nucleus accumbens efferents sensitizes animals to cocaine. J Neurosci. 2002; 22(24): 10856-63. PubMed Abstract

126. Pentkowski NS, Cheung TH, Toy WA, et al:: Protracted withdrawal from cocaine self-administration flips the switch on $5-\mathrm{HT}_{1 \mathrm{~B}}$ receptor modulation of cocaine abuse-related behaviors. Biol Psychiatry. 2012; 72(5): 396-404 PubMed Abstract | Publisher Full Text | Free Full Text

127. Conner TS, Jensen $\mathrm{KP}$, Tennen $\mathrm{H}$, et al:: Functional polymorphisms in the serotonin $1 B$ receptor gene (HTR1B) predict self-reported anger and hostility among young men. Am J Med Genet B Neuropsychiatr Genet. 2010; 153B(1): 67-78. PubMed Abstract | Publisher Full Text | Free Full Text

128. Pattij T, Broersen LM, van der Linde J, et al.: Operant learning and differentialreinforcement-of-low-rate 36-s responding in $5-\mathrm{HT}_{1 \mathrm{~A}}$ and $5-\mathrm{HT}_{1 \mathrm{~B}}$ receptor knockout mice. Behav Brain Res. 2003; 141(2): 137-45. PubMed Abstract | Publisher Full Text

129. Saudou F, Amara DA, Dierich A, et al.: Enhanced aggressive behavior in mice lacking 5-HT1B receptor. Science. 1994; 265(5180): 1875-8. PubMed Abstract | Publisher Full Text

130. Olivier B, Mos J, van Oorschot R, et al:: Serotonin receptors and animal models of aggressive behavior. Pharmacopsychiatry. 1995; 28(Suppl 2): 80-90. PubMed Abstract | Publisher Full Text

131. de Boer SF, Koolhaas $\mathrm{JM}: \mathbf{5}-\mathrm{HT}_{1 \mathrm{~A}}$ and $\mathbf{5}-\mathrm{HT}_{1 \mathrm{~B}}$ receptor agonists and aggression: a pharmacological challenge of the serotonin deficiency hypothesis. Eur $J$ Pharmacol. 2005; 526(1-3): 125-39. PubMed Abstract | Publisher Full Text

132. Rush AJ, Trivedi MH, Wisniewski SR, et al:: Acute and longer-term outcomes in depressed outpatients requiring one or several treatment steps: a STAR*D report. Am J Psychiatry. 2006; 163(11): 1905-17. PubMed Abstract | Publisher Full Text

133. Quesseveur G, Reperant C, David DJ, et al.: $5-\mathrm{HT}_{2 \mathrm{~A}}$ receptor inactivation potentiates the acute antidepressant-like activity of escitalopram: involvement of the noradrenergic system. Exp Brain Res. 2013; 226(2): 285-95. PubMed Abstract | Publisher Full Text

134. Patel JG, Bartoszyk GD, Edwards E, et al:: The highly selective 5hydroxytryptamine (5-HT) receptor antagonist, EMD 281014, significantly increases swimming and decreases immobility in male congenital learned 
helpless rats in the forced swim test. Synapse. 2004; 52(1): 73-5. PubMed Abstract | Publisher Full Text

135. F Weisstaub NV, Zhou M, Lira A, et al:: Cortical $5-\mathrm{HT}_{2 \mathrm{~A}}$ receptor signaling modulates anxiety-like behaviors in mice. Science. 2006; 313(5786): 536-40. PubMed Abstract | Publisher Full Text | F1000 Recommendation

136. Meltzer HY: The role of serotonin in antipsychotic drug action. Neuropsychopharmacology. 1999; 21(2 Suppl): 106S-115S. PubMed Abstract | Publisher Full Text

137. Halberstadt AL, Geyer MA: Multiple receptors contribute to the behavioral effects of indoleamine hallucinogens. Neuropharmacology. 2011; 61(3): 364-81. PublMed Abstract | Publisher Full Text | Free Full Text

138. Diaz SL, Doly S, Narboux-Neme N, et al:: $\mathbf{5}-\mathbf{H T}_{2 \mathrm{~B}}$ receptors are required for serotonin-selective antidepressant actions. Mol Psychiatry. 2012; 17(2): 154-63. PubMed Abstract | Publisher Full Text | Free Full Text

139. F Diaz SL, Narboux-Neme N, Boutourlinsky K, et al.: Mice lacking the serotonin $5-\mathrm{HT}_{28}$ receptor as an animal model of resistance to selective serotonin reuptake inhibitors antidepressants. Eur Neuropsychopharmacol. 2016; 26(2): 265-79. PubMed Abstract | Publisher Full Text | F1000 Recommendation

140. F Bevilacqua L, Doly S, Kaprio J, et al.: A population-specific HTR2B stop codon predisposes to severe impulsivity. Nature. 2010; 468(7327): 1061-6. PubMed Abstract | Publisher Full Text | Free Full Text | F1000 Recommendation

141. Cryan JF, Lucki I: Antidepressant-like behavioral effects mediated by 5hydroxytryptamine $_{2 \mathrm{C}}$ receptors. J Pharmacol Exp Ther. 2000; 295(3): 1120-6. PubMed Abstract

142. F Opal MD, Klenotich SC, Morais M, et al:: Serotonin 2C receptor antagonists induce fast-onset antidepressant effects. Mol Psychiatry. 2014; 19(10): 1106-14. PubMed Abstract | Publisher Full Text | F1000 Recommendation

143. Heisler $\mathrm{LK}$, Zhou L, Bajwa $\mathrm{P}$, et al:: Serotonin $5-\mathrm{HT}_{2 \mathrm{C}}$ receptors regulate anxietylike behavior. Genes Brain Behav. 2007; 6(5): 491-6. PubMed Abstract | Publisher Full Text

144. Higgins GA, Silenieks LB, Altherr EB, et al:: Lorcaserin and CP-809101 reduce motor impulsivity and reinstatement of food seeking behavior in male rats: Implications for understanding the anti-obesity property of 5- $\mathrm{HT}_{2 \mathrm{C}}$ receptor agonists. Psychopharmacology (Berl). 2016; 233(14): 2841-56. PubMed Abstract | Publisher Full Text

145. Griebel G, Perrault G, Sanger DJ: A comparative study of the effects of selective and non-selective $5-\mathrm{HT}_{2}$ receptor subtype antagonists in rat and mouse models of anxiety. Neuropharmacology. 1997; 36(6): 793-802. PubMed Abstract | Publisher Full Text

146. Ramamoorthy R, Radhakrishnan M, Borah M: Antidepressant-like effects of serotonin type-3 antagonist, ondansetron: an investigation in behaviour-based rodent models. Behav Pharmacol. 2008; 19(1): 29-40. PubMed Abstract | Publisher Full Text

147. Kondo M, Nakamura $Y$, Ishida $Y$, et al.: The 5-HT3 receptor is essential for exercise-induced hippocampal neurogenesis and antidepressant effects. Mol Psychiatry. 2015; 20(11): 1428-37. PubMed Abstract | Publisher Full Text

148. Bhatnagar S, Nowak N, Babich L, et al:: Deletion of the $5-\mathrm{HT}_{3}$ receptor differentially affects behavior of males and females in the Porsolt forced swim and defensive withdrawal tests. Behav Brain Res. 2004; 153(2): 527-35. PubMed Abstract | Publisher Full Text

149. Costall B, Naylor RJ: Anxiolytic potential of $\mathbf{5}-\mathbf{H T}_{3}$ receptor antagonists. Pharmacol Toxicol. 1992; 70(3): 157-62. PubMed Abstract | Publisher Full Text

150. F Lucas G, Rymar VV, Du J, et al.: Serotonin $\mathbf{~}_{4}\left(\mathbf{5}-\mathbf{H T}_{4}\right)$ receptor agonists are putative antidepressants with a rapid onset of action. Neuron. 2007; 55(5): 712-25. PubMed Abstract | Publisher Full Text | F1000 Recommendation

151. Mendez-David I, David DJ, Darcet F, et al:: Rapid anxiolytic effects of a 5-HT receptor agonist are mediated by a neurogenesis-independent mechanism. Neuropsychopharmacology. 2014; 39(6): 1366-78. PubMed Abstract | Publisher Full Text | Free Full Text

152. Compan V, Zhou M, Grailhe R, et al.: Attenuated response to stress and novelty and hypersensitivity to seizures in $\mathbf{5 - \mathrm { HT } _ { 4 }}$ receptor knock-out mice. $J$ Neurosci. 2004; 24(2): 412-9.

PubMed Abstract | Publisher Full Text

153. Jean A, Conductier G, Manrique C, et al: Anorexia induced by activation of serotonin 5-HT receptors is mediated by increases in CART in the nucleus accumbens. Proc Natl Acad Sci U S A. 2007; 104(41): 16335-40. PubMed Abstract | Publisher Full Text | Free Full Text

154. Waeber $\mathrm{C}$, Grailhe $\mathrm{R}, \mathrm{Yu}$ XJ, et al:: Putative $\mathbf{5}-\mathrm{Ht}_{5}$ receptors: localization in the mouse CNS and lack of effect in the inhibition of dural protein extravasation. Ann N Y Acad Sci. 1998; 861: 85-90. PubMed Abstract | Publisher Full Tex

155. Svenningsson $\mathrm{P}$, Tzavara ET, Qi $\mathrm{H}$, et al.: Biochemical and behavioral evidence for antidepressant-like effects of $5-\mathrm{HT}_{6}$ receptor stimulation. $J$ Neurosci. 2007; 27(15): 4201-9

PubMed Abstract | Publisher Full Text

156. Carr GV, Schechter LE, Lucki I: Antidepressant and anxiolytic effects of selective 5- $\mathrm{HT}_{6}$ receptor agonists in rats. Psychopharmacology (Berl). 2011; 213(2-3): 499-507.

PubMed Abstract | Publisher Full Text | Free Full Text

157. Mitchell ES, Neumaier JF: $\mathbf{5}-\mathrm{HT}_{6}$ receptors: a novel target for cognitive enhancement. Pharmacol Ther. 2005; 108(3): 320-33. PubMed Abstract | Publisher Full Text

158. Hamon $M$, Doucet $E$, Lefèvre $K$, et al: Antibodies and antisense oligonucleotide for probing the distribution and putative functions of central 5-HT receptors. Neuropsychopharmacology. 1999; 21(2 Suppl): 68S-76S. PubMed Abstract | Publisher Full Text

159. F Guscott M, Bristow LJ, Hadingham K, et al.: Genetic knockout and pharmacological blockade studies of the $5-\mathrm{HT}_{7}$ receptor suggest therapeutic potential in depression. Neuropharmacology. 2005; 48(4): 492-502. PubMed Abstract | Publisher Full Text | F1000 Recommendation

160. Ballaz SJ, Akil H, Watson SJ: The $5-\mathrm{HT}_{7}$ receptor: role in novel object discrimination and relation to novelty-seeking behavior. Neuroscience. 2007; 149(1): 192-202.

PubMed Abstract | Publisher Full Text 


\section{Open Peer Review}

\section{Current Peer Review Status:}

\section{Editorial Note on the Review Process}

Faculty Reviews are review articles written by the prestigious Members of Faculty Opinions. The articles are commissioned and peer reviewed before publication to ensure that the final, published version is comprehensive and accessible. The reviewers who approved the final version are listed with their names and affiliations.

\section{The reviewers who approved this article are:}

\section{Version 1}

\section{Irwin Lucki}

Department of Psychiatry, Department of Pharmacology, University of Pennsylvania, Philadelphia, PA, USA

Competing Interests: No competing interests were disclosed.

\section{Randy Blakely}

Department of Biomedical Sciences, Charles E. Schmidt College of Medicine, Florida Atlantic University, Jupiter, FL, 33458, USA

Competing Interests: No competing interests were disclosed.

\section{John Neumaier}

Department of pharmacology, University of Washington, Seattle, WA, USA

Competing Interests: No competing interests were disclosed.

The benefits of publishing with F1000Research:

- Your article is published within days, with no editorial bias

- You can publish traditional articles, null/negative results, case reports, data notes and more

- The peer review process is transparent and collaborative

- Your article is indexed in PubMed after passing peer review

- Dedicated customer support at every stage

For pre-submission enquiries, contact research@f1000.com 